Indo. J. Chem. Res., 2019, 6(2), 74-80

\title{
STUDI KINETIKA ANTIBAKTERI DARI HASIL PIROLISIS CANGKANG BIJI JAMBU METE TERHADAP Staphylococcus aureus
}

\author{
Kinetic Study Antibacterial Of Pyrolysis Products Fromcashew Nut Shell Againts \\ Staphylococcus aureus
}

\author{
Laily Nurliana*1, Rustam Musta ${ }^{2}$ \\ ${ }^{1}$ Department of Chemitry, Math and Nature Science Faculty, Halu Oleo University \\ ${ }^{2}$ Department of Chemitry, Teacher Training dan Education Faculty, Halu Oleo University \\ Kampus Bumi Tridarma ; Anduonohu Kendari, Southeast Sulawesi, Telp. (0401)391929/Fax.(0401)390496 \\ *Corresponding author, e-mail: laylinurliana@gmail.com
}

Received: Nov. 2018 Published: Jan. 2019

\begin{abstract}
Research on kinetics antibacterial from pyrolysis product of cashew nut shell againts Staphylococcus aureus have been carried out. Cashew nuts are prepared by separating the shell and seeds for pyrolysis. The results of $S$. aureus antibacterial activity test results pyrolysis pyrolysis products shell cashew nut showed inhibition is different for each variation of the concentration of $12.5 \%, 25 \%, 50 \%, 75 \%$ and $100 \%$ with inhibition of successive $0.87 ; 0.97 ; 1.38 ; 1.47$ and $1.61(\mathrm{~cm})$ respectively. Based on these results it can be said that the result of the pyrolysis of cashew nut shells provide a response inhibition that were at concentrations of 12.5 and $25 \%$. While the concentration of 50\%,75\%, and $100 \%$ response inhibitory power is included in the strong category on the growth of $S$. aureus. Order of the reaction of the antibacterial activity of $S$. aureus from the pyrolysis products obtained cashew nut shell 0.3157 with activity rate constant of 0.38 . The concentration of pyrolysis products of pyrolysis results cashew nut shell the minimum recommended for use as an antibacterial S.aureus.
\end{abstract}

Keywords: Cashew nut shells, pyrolysis, S.aureus, antibacterial, chemical kinetics.

\section{PENDAHULUAN}

Potensi limbah cangkang biji jambu mete di Indonesia cukup besar, sehingga perlu dimanfaatkan cairan ekstraknya yang disebut Cashew Nut Shell Liquid (CNSL) (Saenabet al., 2016).Warsono et al., (2013) menyatakan bahwa CNSL merupakan minyak yang tersusun dari senyawa fenolat kompleks dengan rantai karbon panjang bercabang dan tidak jenuh. Komponen utama penyusun CNSL terdiri atas senyawa asam anakardat, kardanol, kardol dan 2-metil kardol yang merupakan senyawa fenol alami (Towaha dan Nur, 2011).

Salah satu teknologi alternatif yang dapat menjadi solusi bagi penanganan permasalahan limbah cangkang biji jambu mete ialah dengan teknik pirolisis (Saenab et al., 2016). Pirolisis berasal dari dua kata yaitu pyro yang berarti panas dan lysis berarti penguraian atau degradasi, sehingga pirolisis berarti penguraian biomassa karena panas pada suhu lebih dari $150{ }^{\circ} \mathrm{C}$ (Hermayana, 2017). Pirolisis adalah dekomposisi kimia bahan organik melalui proses pemanasan tanpa oksigen, material mentah akan mengalami pemecahan struktur kimia menjadi fase gas (Wiraputra, 2017). Proses pirolisis menghasilkan produk berguna berupa uap panas yang kemudian dikondensasi menjadi liquid (bio-oil), syngas (bio-gas) dan char (bio-arang). Pada proses ini, liquid (bio-oil) yang dihasilkan dari proses pirolisis diperkirakan masih mengandung tar yang kemudian harus dimasukkan ke dalam tungku destilasi.

Kandungan komponen penyusun bio-oil hasil destilasi meliputi senyawa fenol, senyawa asam dan senyawa hidrokarbon polisiklis aromatis. Senyawa fenol dalam kulit biji jambu mete mempunyai sifat khas, yang berperan dalam bidang industri kesehatan salah satunya adalah sebagai anti bakteri (Kusrini dan Mahendra 2003). Seperti penelitian yang pernah dilakukan sebelumnya oleh Poeloengan dan Praptiwi (2010), mengenai uji aktivitas anti bakteri dari ekstrak kulit buah manggis diperoleh hasil bahwa dalam ekstrak kulit buah manggis terdapat senyawa fenol yang mempunyai kecenderungan untuk mengikat protein, sehingga mengganggu proses metabolisme pada bakteri gram positif $S$. aureus. Anti bakteri adalah zat 
yang menghambat pertumbuhan bakteri dan di gunakan secara khusus untuk mengobati infeksi bakteri. Maharani et al. (2016) menyatakan bahwa aktivitas senyawa fenol dalam menghambat pertumbuhan bakteri yaitu bekerja dengan meracuni sitoplasma, merusak dan menembus dinding serta mengendapkan protein sel bakteri.

Aktivitas anti bakteri hasil pirolisis cangkang biji jambu mete ditentukan berdasarkan daya hambat yang diukur menggunakan zona bening. Aktivitas anti bakteri tersebut dapat dipelajari pola daya hambatnya menggunakan pendekatan kinetika kimia dengan menghitung orde reaksi dan tetapan aktivitas lajunya. Triyono, dkk (1998) menyatakan bahwa dengan hanya perubahan $[\mathrm{A}]_{\mathrm{o}}$ saja dan hukum laju reaksi diasumsikan $\mathrm{r}=\mathrm{k}[\mathrm{A}]^{\mathrm{a}}[\mathrm{B}]^{\mathrm{b}}[\mathrm{C}]^{\mathrm{c}}$ maka orde reaksi dapat ditentukan. Dengan demikian, untuk reaksi penghambatan aktifitas antibakteri yang hanya menggunakan satu perekasi yang konsentrasinya bervariasi dapat digunakan untuk menghitung orde reaksi. Jika orde telah diketahui maka berdasarkan hukum lajunya dapat dihitung besarnya tetapan laju pada temperatur yang dipilih pada masa inkubasi. Hal ini dikarenakan tetapan laju akan berubah apabila reaksi berlangsung pada temperatur yang berbeda. Triyono, dkk (1998) menyatakan konstanta laju merupakan fungsi temperatur. Orde reaksi hanya dapat dihitung secara eksperimen dan hanya dapat diramalkan jika suatu mekanisme reaksi diketahui seluruh orde reaksi yang dapat ditentukan sebagai jumlah dari eksponen untuk masing-masing reaktan (Naomi et al. 2013, Latupeirissa, dkk., 2018)

Berdasarkan latar belakang tersebut, maka perlu dilakukan penelitian tentang studi kinetika anti bakteri dari hasil pirolisis cangkang biji jambu mete terhadap $S$. aureus.

\section{METODOLOGI}

\section{Bahan}

Bahan-bahan yang digunakan dalam penelitian ini adalah sampel cangkang kulit jambu mete segar (Anacardium occidentale),Staphylococcus aureus ATCC 25923 , amoxilin, pepton $2 \%$, agar $4 \%, 1 \% \mathrm{NaCI}$, minyak tween, akuades, kertas saring Whatman, plastik wrap, kasa, kertas label, kapas steril dan alumunium foil.
Alat

Alat-alat yang digunakan dalam penelitian ini adalah satu set alat pirolisis alat sederhana, gelas kimia $1000 \mathrm{~mL}$, inkubator, neraca analitik (Acis), autoklaf (Wisecclave), waterbath (HWS24), lemari pendingin (SHARP), pipet mikro (DRAGON ONEMED), laminar air flow cabinet, shaker incubator (Ratex), lampu UV, hot plate, mistar, spidol, tabung eppendorf, kawat ose, cawan petri (Pyrex), gelas ukur (Pyrex), gelas kimia (Pyrex), erlenmeyer (Pyrex), corong (Pyrex), spritus, spatula, pipet ukur, oven, pipet tetes, botol vial, botol gelap, korek api dan pisau.

\section{Prosedur Kerja \\ Pengambilan dan Pengolahan Sampel Cangkang Biji Jambu mete}

Sampel biji jambu mete yang digunakan diperoleh dari daerah perkebunan jambu mete di Desa Kapota, Kabupaten Wakatobi Kecamatan Wangi-wangi Selatan, Sulawesi Tenggara. Biji jambu mete dipisahkan dari cangkangnya, kemudian cangkang biji jambu mete dianginanginkan.

\section{Proses Pirolisis}

Sampel cangkang biji jambu mete ditimbang sebanyak $2,5 \mathrm{~kg}$ lalu dimasukkan ke dalam reaktor alat pirolisis sederhana, kemudian dipirolisis. Proses pirolisis berlangsung sampai destilat berhenti keluar.

\section{Pengujian Aktivitas Antibakteri Sterilisasi alat dan bahan}

Seluruh alat dicuci bersih dan dikeringkan. Botol vial, tabung reaksi, erlenmeyer, cawan petri dibungkus dengan kertas. Kemudian semuanya disterilkan dengan autoklaf pada tekanan $121 \mathrm{MPa}$ selama 15 menit. Pengerjaan aseptis berlangsung di dalam Laminar Air Flow yang sebelumnya telah dibersihkan dengan larutan alkohol 70\%, lalu proses sterilisasi dengan lampu UV yang telah menyala selama kurang lebih 1 jam sebelum digunakan dalam proses uji antibakteri (Sultana, 2014).

\section{Pembuatan dan Sterilisasi Media}

Medium Nutrient Agar (NA) adalah medium yang umum digunakan untuk menumbuhkan mikroorganisme. Medium ini mengandung $2 \%$ pepton, $1,5 \%$ yet estrak, $4 \%$ 
agar dan $1 \% \mathrm{NaCl}$. Pada penelitian ini digunakan NA (Merck 2017) sebanyak 22,1 g NA dilarutkan dengan $260 \mathrm{~mL}$ akuades dalam erlenmeyer, kemudian disterilkan menggunakan autoklaf pada tekanan $121 \mathrm{MPa}$ (Sultana, 2014).

\section{Peremajaan mikroorganisme}

Mikroorganisme yang digunakan dalam penelitian ialah S. aureus ATCC 25923 spesies bakteri. Bakteri ini diremajakan dengan menginokulasi 2 ose dari bakteri, kemudian dimasukkan kedalam tabung reaksi yang berisi $10 \mathrm{~mL}$ media cair steril ( $2 \%$ pepton, $1,5 \%$ yeast estrak dan $4 \% \mathrm{NaCl}$ ) dan diinkubasi selama 24 jam (Sultana, 2014).

\section{Pengujian Aktivitas Antibakteri}

Media NA cair dipipet sebanyak $20 \mathrm{~mL}$, kemudian dimasukkan dalam eppendorf dan ditambahkan 10 uL inokulum bakteri $S$. aureus ATCC 25923 dan dihomogenkan. Setelah homogen tuangkan dalam cawan petri dengan gerakan melingkar sampai media merapat pada permukaan cawan petri, lalu didiamkan beberapa menit hingga memadat. Kemudian ditempatkan kertas cakram (berdiameter $0,5 \mathrm{~cm}$ ) yang telah direndam dalam larutan uji $(100 \%$ destilat cangkang jambu mete, $75,50,25$, dan 12,5\% serta amoxilin sebagai kontrol positif, minyak tween sebagai kontrol negatif) pada permukaan media padat. Setelah itu, cawan petri ditutup rapat dan dibungkus dengan plastik wrap. Selanjutnya diinkubasi selama 1 x 24 jam pada suhu ruang. Dilakukan pengamatan dan diukur zona hambat yang terbentuk (Bangjavicenna, 2008).

\section{Pengolahan dan Analisis Data}

Data yang diperoleh antara lain nilai zona bening isolat pada uji antibakteri dan tinjauan aspek kinetikanya meliputi orde reaksi dan tetapan laju reaksi aktivitas antibakteri dengan menggunakan metode regresi linear yang ditentukan dengan menggunakan persamaan (Dybkov, 2013):

$$
\mathrm{r}=\mathrm{k}[\mathrm{A}]^{\mathrm{n}} .
$$

Dimana $\mathrm{r}=$ laju, $\mathrm{k}=$ konstanta laju reaksi, $[\mathrm{A}]=$ konsentrasi zat, $\mathrm{n}=$ orde reaksi.

Laju dapat dipandang sebagai bertambahnya hasil reaksi atau berkurangnya pereaksi untuk setiap satuan waktu (Petruci, 1992). Dengan demikian laju dalam hubungan dengan aktifitas anti bakteri dapat dipandang sebagai pertambahan diameter zona bening setelah selang waktu tertentu atau $\mathrm{r}=$ diameter zona bening (ZB)/satuan waktu (t) dan karena waktu pengukuran zona bening adalah tetap maka:

$$
\mathrm{Jika} \mathrm{r}=k[\mathrm{~A}]^{\mathrm{n}} \rightarrow \mathrm{ZB} / \mathrm{t}=k[\mathrm{~A}]^{\mathrm{n}}
$$

karena $\mathrm{k}$ dan $\mathrm{t}$ adalah konstan maka kt juga akan bernilai konstan $=\mathrm{k}^{\prime}$ yang merupakan tetapan yang berlaku untuk satuan waktu pengukuran zona bening yang dipilih berdasarkan referensi. akibatnya:

$$
\mathrm{ZB}=k^{\prime}[\mathrm{A}]^{\mathrm{n}} \text { maka: } \ln \mathrm{ZB}=\ln k^{\prime}+\mathrm{n} \ln [\mathrm{A}]
$$

Berdasarkan hal-hal tersebut maka dapat dipandang bahwa laju identik dengan zona bening. Dari regresi linear akan diperoleh persamaan :

$$
\mathrm{y}=\mathrm{a}+\mathrm{bx} \text { atau } \ln \mathrm{ZB}=\ln k^{\prime}+\mathrm{n} \ln [\mathrm{A}]
$$

Hal ini berarti bahwa jika dibuat plot hubungan $\ln [\mathrm{A}]$ terhadap $\ln \mathrm{ZB}$ maka akan diperoleh :

$$
\begin{aligned}
& a=\ln k^{\prime} \\
& k^{\prime}=e^{a} \quad \text { (berlaku untuk waktu inkubasi } \\
& \quad \text { yang telah dipilih) } \\
& b=n=\text { orde }
\end{aligned}
$$

\section{HASIL DAN PEMBAHASAN}

\section{Pengambilan dan Pengolahan Sampel Cangkang Biji Jambu Mete}

Sampel jambu mete yang digunakan dalam penelitian ini diperoleh dari daerah perkebunan jambu mete di Desa Kapota, Kabupaten Wakatobi Kecamatan Wangi-wangi Selatan, Sulawesi Tenggara. Sampel yang digunakan yaitu cangkang biji jambu mete segar. Sampel jambu mete dipisahkan bagian isi dan cangkangnya. Cangkang jambu mete dikeringkan dengan cara diangin-anginkan. Proses pengeringan dilakukan pada suhu ruang tanpa terkena sinar matahari langsung. Proses pengeringan bertujuan untuk menguapkan sebagian air dalam bahan agar kadar air yang terdapat dalam sampel berkurang, sehingga proses ekstraksi lebih mudah. 

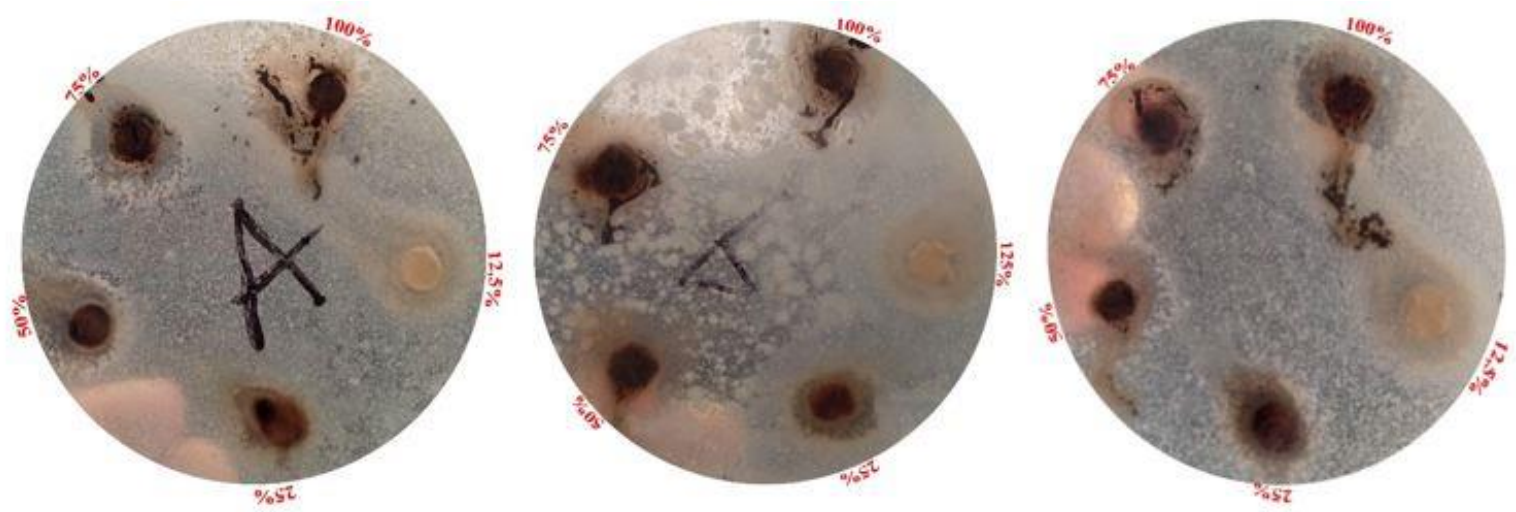

Gambar 1 Penampakan zona bening uji aktivitas hasil pirolisis cangkang biji jambu mete terhadap bakteri $S$. aureus

Proses Pirolisis Cangkang Biji Jambu Mete

Proses pirolisis cangkang biji jambu mete pada penelitian ini menggunakan metode pirolisis sederhana. Keunggulan metode ini adalah harganya yang relatif murah, dan tidak memakan waktu yang lama dalam poses pemisahannya. Pirolisis merupakan proses penguraian yang tidak teratur dari bahan-bahan organik yang disebabkan oleh adanya pemanasan tanpa berhubungan dengan udara luar. Reaksi pirolisis akan menghasilkan produk berupa padatan, cairan dan gas (Awaluddin, 2007).

Sampel cangkang biji jambu mete dipirolisis dengan bantuan pemanasan sehingga mengalami reaksi kondensasi dari asap cair menjadi cairan kental berwarna hitam. Pada saat pirolisis, energi panas mendorong terjadinya oksidasi sehingga molekul karbon yang kompleks terurai, sebagian besar menjadi karbon atau arang (Nuryati et al., 2015). Hasil pirolisis cangkang biji jambu mete yang diperoleh pada penelitian ini adalah asap cair atau biosmoke yang berwarna hitam kecoklatan dengan rendemen sebesar 38,5\%. Jumlah rendemen tersebut sesuai dengan penelitian Saenab (2016) yang jumlahnya lebih kecil dibandingkan penelitian Gonzales (2005) dalam Saenab (2016) tentang pirolisis cangkang biji kenari yang dihasilkan rendemen sebesar $44,3 \%$. Hal ini disebabkan alatpirolisis yang digunakan dalam penelitian ini masih sederhana sehingga asap yang keluar belum tertampung secara sempurna.

\section{Uji Aktivitas Antibakteri Staphylococcus aureus Hasil Pirolisis Cangkang Biji Jambu Mete}

Hasil analisis uji aktivitas antibakteri hasil pirolisis cangkang biji jambu mete dalam menghambat pertumbuhan bakteri $S$. aureus dapat dilihat pada Gambar 1 dan 2:

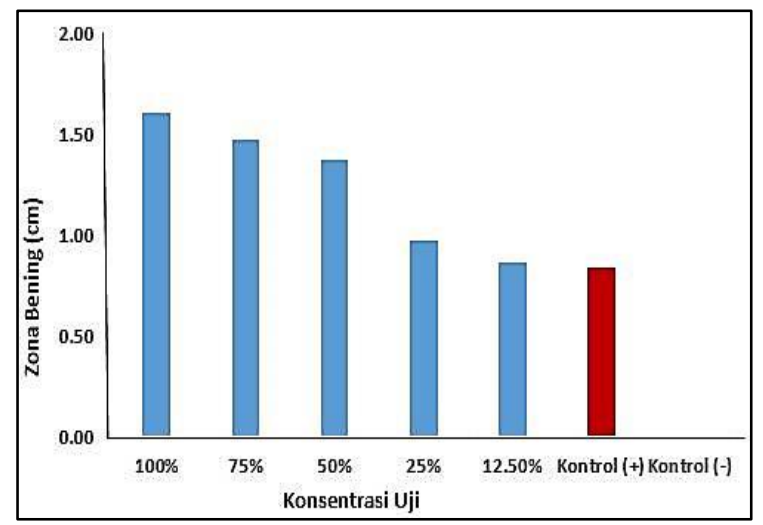

Gambar 2 Diagram uji aktivitas hasil pirolisis cangkang biji jambu mete terhadap bakteri $S$.

aureus

Gambar 2 menunjukkan bahwa pada tiaptiap variasi konsentrasi hasil pirolisis cangkang biji jambu mete memiliki aktivitas yang berbedabeda terhadap daya hambat bakteri $S$. aureus.Data tersebut juga memperlihatkan bahwa diameter zona bening hasil pirolisis cangkang biji jambu mete di tiap-tiap konsentrasi $12,5 \%, 25 \%, 50 \%, 75 \%$, dan $100 \%$ berturut-turut 0,$87 ; \quad 0,97 ; \quad 1,38 ; \quad 1,47 \quad$ dan $1,61 \quad(\mathrm{~cm})$. Berdasarkan hasil tersebut, diketahui bahwa setiap peningkatan konsentrasi sampel akan meningkatkan zona bening yang dihasilkan.

Menurut Rastina et al., (2015), kriteria kekuatan daya hambat antibakteri dijelaskan berdasarkan parameter sebagai berikut: diameter zona hambat $5 \mathrm{~mm}$ atau kurang dikategorikan lemah, zona hambat 5-10 $\mathrm{mm}$ dikategorikan 
sedang, zona hambat $10-20 \mathrm{~mm}$ dikategorikan kuat dan zona hambat $20 \mathrm{~mm}$ atau lebih dikategorikan sangat kuat. Berdasarkan kriteria tersebut, maka hasil pirolisis cangkang jambu mete memberikan respon daya hambat yang sedang pada konsentrasi 12,5 dan25\%. Sedangkan pada konsentrasi $50 \%, 75 \%$, dan $100 \%$ respon daya hambatnya termasuk dalam kategori kuat terhadap pertumbuhan bakteri $S$. aureus.

Adanya daya hambat antibakteri dalam penelitian ini kemungkinan disebabkan oleh kandungan senyawa fenol dan asam organik dalam hasil pirolisis jambu mete. Seperti pada penelitian Saenab et al.(2016) dua senyawa dominan yang berperan sebagai bakteriostatik adalah fenol dan asam-asam organik yang mampu mengontrol pertumbuhan bakteri.

Cara kerja asam organik dalam menghambat pertumbuhan bakteri yaitu dengan sifatnya yang asam menyebabkan $\mathrm{pH}$ di dalam sel menjadi rendah dan dapat mengubah permeabilitas membran sel yang menyebabkan sistem transpor bahan pada bakteri patogen menjadi hancur. Hal ini dapat menyebabkan sel menjadi rusak, diikuti dengan terganggunya sintesis komponen penyusun dinding sel, akibatnya sel menjadi lemah dan lisis (Pasaribu dan Wina, 2017).

Mekanisme yang menyebabkan penghambatan dalam pertumbuhan bakteri diduga disebabkan adanya interaksi senyawa fenol dan turunannya dengan sel bakteri. Senyawa-senyawa ini berikatan dengan protein pada bakteri melalui ikatan non spesifik membentuk kompleks protein-fenol. Pada konsentrasi rendah, terbentuk kompleks proteinfenol dengan ikatan yang lemah dan segera mengalami peruraian, kemudian merusak membran sitoplasma dan menyebabkan kebocoran isi sel, sehingga pertumbuhan bakteri terhambat. Sedangkan pada konsentrasi tinggi, zat tersebut berkoagulasi dengan protein seluler dan membran sitoplasma mengalami lisis (Dinda, 2008).

Tinjauan Aspek Kinetik Aktivitas Anti Bakteri dari Hasil Pirolsis Cangkang Biji Jambu Mete terhadap Staphylococcus aureus

Zona bening merupakan indikasi adanya aktifitas antibakteri (Lay, 1994 dalam Muharni, dkk 2014). Sementara itu menurut Ruhana (2017) menyebutkan bahwa zona bening adalah daerah yang tidak ditumbuhi bakteri dalam satuan tertentu. Lebih lanjut, Mulyadi, dkk (2017) mengemukkan bahwa zona bening yang terbentuk pada media yang telah diinokulasi bakteri di sekitar cakram kertas yang dicelupkan sampel menunjukkan aktifitas penghambatan. Hal tersebut berarti bahwa ada tahapan reaksi kimia sebelum zona bening terbentuk.

Sehingga zona bening sesungguhnya adalah hasil akhir dari aktifitas reaksi penghambatan yang berjalan seiring waktu, dengan demikian laju terbentuknya zona bening dapat dihitung dari diameter zona bening per waktu inkubasi. Laju dapat dipandang sebagai bertambahnya hasil reaksi atau berkurangnya pereaksi untuk setiap satuan waktu (Petruci, 1992).

Aspek kinetik produk pirolisis cangkang biji jambu mete terhadap aktivitas anti bakteri dilihat melalui hubungan zona bening dengan konsentrasi yang digunakan untuk anti bakteri. Analisisnya dilakukan menggunakan pendekatan regresi linear yang hasilnya dapat diperlihatkan pada Gambar 3 sebagai berikut:

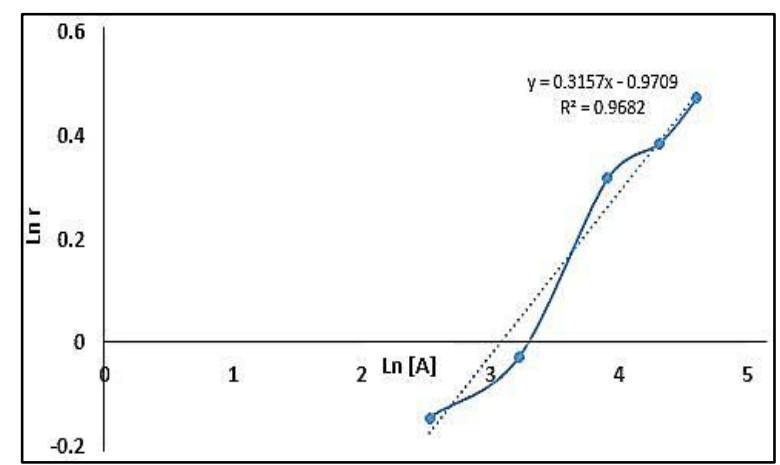

Gambar 3 Hasil uji kinetika anti bakteri hasil pirolisis dalam menghambat pertumbuhan bakteri S.aureus

Gambar 3 memperlihatkan persamaan regresi dengan bentuk $y=0,3157 x-0,9709$. Persamaan tersebut menunjukkan bahwa orde reaksi hasil pirolisis cangkang biji jambu mete sebagai anti bakteri sebesar 0,3157. Sementara itu, tetapan lajunya dapat diperoleh dengan $\mathrm{e}^{-0.9709}=0,38$. Nilai tetapan tersebut hanya berlaku untuk selang waktu masa ikubasi untuk pengukuran zona bening dalam penelitian ini adalah $24 \mathrm{jam}$. Orde reaksi 0,3157 dapat diartikan bahwa ada pengaruh konsentrasi terhadap laju reaksi hal ini karena reaksi berada diantara orde 0 dan orde 1 , yang dapat diartikan bahwa ada peningkatan zona bening akibat 
bertambahnya konsentrasi hasil pirolisis, karena rekasi tidak berorde tepat 0 namun peningkatan tersebut juga tidak berbanding lurus dengan konsentrasi hasil pirolisis karena reaksi juga tidak berorde 1. Bird (1993) menyatakan bahwa suatu reaksi dikatakan orde satu terhadap salah satu pereaksinya jika laju reaksi berbanding lurus dengan konsentrasi pereaksi itu dan reaksi dikatakan berorde nol terhadap salah satu pereaksinya apabila perubahan konsentrasi pereaksi tersebut tidak mempengaruhi laju reaksi.

Berdasarkan data pada Gambar 3, diperlihatkan linearitas dari hubungan antara log konsentrasi terhadap $\log$ zona bening yaitu $\mathrm{r}^{2}$ :0,9682 atau dikatakan akurat seperti yang dijelaskan oleh Sudjana (2005) dalam Anggreini (2008), bahawa koefesien korelasi menunjukkan kekuatan (strength) hubungan linear dan arah hubungan dua variabel acak. Jika koefesien korelasi positif, maka kedua variabel mempunyai hubungan searah. Nilai korelasi ini dijelaskan dalam kriteria dimana nilai $r^{2}=0,75-0,99$ : Korelasinya dikategorikan sangat kuat.

Orde reaksi dan tetapan laju yang telah ditentukan, dapat dimanfaatkan untuk menghitung konsentrasi hasil pirolisis cangkang biji jambu meteyang daya hambat (zona bening) sama dengan daya hambat (zona bening) kontrol positif. Hasil perhitungan memperlihatkan bahwa agar diperoleh zona bening yang sama dengan standar positif maka konsentrasi yang diperlukan sebesar $24,78 \%$. Hal tersebut dapat bermakna bahwa besarnya konsentrasi hasil pirolisis cangkang biji jambu meteminimal yang dapat digunakan sebagai antibakteri $S$. aureus harus sebesar $24,78 \%$.

\section{KESIMPULAN}

Hasil uji aktivitas antibakteri S. aureus hasil pirolisiscangkang biji jambu metemenunjukkan daya hambat yang berbeda untuk setiap variasi konsentrasi $12,5 \%, 25 \%, 50 \%$, 75\% dan $100 \%$ dengan daya hambat berturut- 0,$87 ; 0,97 ; 1,38$; 1,47 dan 1,61 $(\mathrm{cm})$. Berdasarkan hasil tersebut dapat dikatakan bahwa hasil pirolisis cangkang jambu mete memberikan respon daya hambat yang sedang pada konsentrasi $12,5 \%$ dan $25 \%$. Sedangkan pada konsentrasi $50 \%, 75 \%$, dan $100 \%$ respon daya hambatnya termasuk dalam kategori kuat terhadap pertumbuhan bakteri $S$. aureus. Orde reaksi dari aktivitas antibakteri $S$. aureus dari hasil pirolisis cangkang biji jambu mete diperoleh sebesar 0,3157 dengan tetapan laju aktivitas untuk pengukuran zona bening setelah 24 jam sebesar 0,38. Adapun konsentrasi hasil pirolisis cangkang biji jambu mete minimal yang dianjurkan untuk digunakan sebagai antibakteri S. aureus sebesar $24,78 \%$.

\section{DAFTAR PUSTAKA}

Anggraeni, M., 2008, Kajian Penggunaan Poly Alumunium Chloride (PAC) dalam Proses Pemurnian Nira Aren dan Lama Pemurnian Terhadap Karateristik Nira Aren (Arenga pinnata Merr), Skripsi, Prodi Teknologi Pangan, Fakultas Teknologi Industri Pertanian, Universitas Padjadjaran, Jatinangor.

Awaluddin, A., 2007, Proses Pencairan Langsung Biomassa menjadi Bio Oil dengan menggunakan Thermo Oil, Proposal I MHERE Project, HEI IU Universitas Riau, Dinas Perkebunan Provinsi Kalimantan Selatan, 2009.

Bagjavicenna, E., 2008, Potensi Propolis Lebah Trigona spp sebagai Bahan Antimikroba Ketombe, Skripsi, Program Studi Biokimia, Fakultas Matematika dan Ilmu Pengetahuan Alam Institut Pertanian Bogor, Bogor.

Bird, T., 1993, Kimia Fisik Untuk Universitas, alih bahasa : Kwee le Tjien, Jakarta : PT Gramedia Pustaka Utama.

Dybkov, V.I., 2013, Chemical Kinetics, IPMS Publications, Kyiv, Ukraine.

Dinda, 2008, Minimal Inhibitor Concentraction (MIC), Dasar-Dasar Mikrobiologi, Djambatan. Jakarta.

Hermayana, R.F.S., 2017, Pirolisis Campuran Bagas Tebu Dan Minyak Biji Karet Dengan Perbandingan Reaktan Yang Berbeda Menjadi Bahan Bakar Cair Menggunakan Zeolit-A Berbasis Silika Sekam Padi Sebagai Katalis, Skripsi, Jurusan Kimia, Fakultas Matematika dan Ilmu Pengetahuan Alam, Universitas Lampung.

Kusrini, D., Mahendra I., 2003, Asam Anakardat dari Kulit Biji Jambu mete (Anacardium occidentale L) Yang Mempunyai Aktivitas sitotoksik, J. Kim. Sains \& Apl., 6(1):17-19.

Latupeirissa, J., Tanasale, M., Musa, S., 2018, Kinetika Adsorpsi Zat Warna Metilen Biru Oleh Karbon Aktif Dari Kulit Kemiri 
(Aleurites Moluccana (L) Willd), Indo. J. Chem. Res., 6(1), 524-533.

Maharani, T., Dede S., Sandra H., 2016, Karakterisasi Senyawa Hasil Isolasi dari Ekstrak Etil Asetat Daun Namnam (Cynometra Cauliflora L.) yang Memiliki Aktivitas Antibakteri., Jurnal Penelitian dan Pengembangan Ilmu Kimia, 2(1), 5562.

Naomi, P., Anna M., Lumban G.M. , Yusuf T., 2013, Pembuatan Sabun Lunak dari Minyak Goreng Bekas Ditinjau dari Kinetika Reaksi Kimia, Jurnal Teknik Kimia, 2(19), 42-48.

Nuryati, Jaka D.J., Meldayanoor, 2015, Perancangan Dan Aplikasi Alat Pirolisis Untuk Pembuatan Asap Cair, Jurnal Teknologi Agro-Industri, 2(1), 1-8.

Pasaribu, T., Wina E., 2017, Komparasi Aktivitas Tiga Jenis Asap Cair Perhadap Pertumbuhan Mikroba Secara In Vitro, Prosiding Seminar Nasional Teknologi Peternakan dan Veteriener, 679-689.

Petrucci, R.H., 1992, Kimia Dasar Prinsip dan Terapan Modern, Edisi Keempat, Jilid 2, Editor Penerjemah: Suminar Achmadi, Penerbit Erlangga, Jakarta.

Poeloengan, M., Praptiwi, 2010, Uji aktivitas antibakteri Ekstrak Kulit Buah Manngis (Garcinia mangostana Linn), Media Litbang Kesehatan, XX (2), 65-69.

Rastina, Mirnawati S., Letje W., 2015, Aktivitas Antibakteri Ekstrak Etanol Daun Kari (Murraya koenigii) Terhadap Staphylococcus aureus, Escherichia coli, dan Pseudomonas sp., Jurnal Kedokteran Hewan, 9(2), 185-188.
Saenab, A., Wiryawan, K.G., Retnany., Wina, E. 2016. Karakteristik Fisik dan Kimia dari Produk Bioindustri Cangkang Jambu Mete (An acardium occidentale), Jurnal Littri, 22(2), 81-90.

Sultana, S., Shahidullah, A.S.M., Islam, Md. M., Wasey, A.F.S.A., Nahar, S., 2014, Antibacterial effect of Aqueous Neem (Azadirachta indica) leaf extract, crude neem leaf paste, and Ceftriaxone against Staphylococcus aureus, Escherichia coli and Pseudomonas aeruginosa, Malays.J.Med.Bio.Res, 2(2), 89-100.

Towaha, J., Nur, R.A. 2011, Pemanfaatan Cashew Nut Shell Liquid Sumber Fenol Alami pada Industri, Buletin RISTRI, 2(2), 187-198.

Triyono, Bambang S., Iqmal T., 1998, Buku Ajar Kinetika Kimia, Jurusan Kimia, FMIPA UGM: Jogjakarta.

Warsono, L.B., Windi, A.,Bambang, S.A., 2013, Ekstraksi Cashew Nut Shell Liquid (CNSL) dari Kulit Jambu Mete dengan Menggunakan Metode Pengepresan. Jurnal Teknosains Pangan. 2(2), 84-92.

Wiraputra, A.F, 2017, Pengaruh Pyrolysis NonIsothermal Terhadap Kualitas Bio-Oil Dari Sampah Real Kota Bandar Lampung, Skripsi, Jurusan Teknik Mesin, Fakultas Teknik Universitas Lampung. 